\title{
Socio-Economic Importance of Bus Rapid Transit: A Panacea to Sustainable Transport Development in Nigeria
}

\author{
Babatope Andrew OGUNDARE* \\ Department of Geography, College of Education, Ikere-Ekiti, Ekiti State.
}

*Corresponding Author: Babatope Andrew OGUNDARE, Department of Geography, College of Education, Ikere-Ekiti, Ekiti State.

\begin{abstract}
Transport plays a crucial role in urban development by providing access to people for education, markets, employment, recreation, health care and other key services. Especially in cities of the developing world, enhanced mobility for the poor and vulnerable groups is one of the most important preconditions for achieving sustainable development. The study therefore aims at determining the perceived socio-economic benefits of bus rapid transit (BRT) for the patrons of public bus system and addressed transportation challenges in order to create a functional, lively and sustainable city in Nigeria. The study adopted an empirical research design to investigate BRT services in Lagos State. The study was based on the data drawn from a target population which is Lagos BRT communities. The sampling unit was based on pilot study using the number of BRT fleets in operation and their capacities, where a total number of 539 BRT users form the sample size. The data for the study were obtained from primary sources through administration of questionnaires. The F-test statistics revealed interactive effect of benefits derived from BRT on its challenges to the commuters. It was found that the F-cal (1029.943) was greater than Table value (2.600) at 0.05 level of significant. This led to the rejection of the hypothesis stated and thus, the perceived socio-economic benefits of BRT are significantly higher than its challenges to commuters in Lagos metropolis. The study recommends the use of BRT as a good alternative to other public/ private transportation to enhance sustainable living in the cities.
\end{abstract}

Keywords: Bus rapid transit, sustainable development, cities, transportation, socio-economic, commuters

\section{INTRODUCTION}

The life of a metropolis depends upon its transportation system, and a healthy urban economy requires that transport be smooth and efficient. The automobile-centred, unplanned travel networks of today are proving increasingly inefficient as urban activity and congestion grow. Further, the costs of continuing to support automobile-based transport systems are forbidding, in terms of space absorbed for highways, energy requirements, and ecological consequences. Aware of these factors, most metropolitan areas are moving to coordinate and streamline their transport systems, and to provide mass transit alternatives to the automobiles. These shifts have required urban transportation planners to forecast accurately the response of transportation demand to changes in the attributes of the transport system.

Thus, transportation is concerned with mobility, particularly how this mobility is taking place in the context of a wide variety of conditions. Mobility is a geographical endeavour since it trades space for a cost (Rodrique, Comtois and Slack, 2006; Ogunbodede, 2017). Technological and economic forces have changed this balance many times in the past, but in recent decades a growing amount of space has been made accessible at a similar cost. It is thus not surprising to realize that technology permitted improvements in transport speed, capacity and efficiency. Individuals and corporations have been able to take advantage of this improved mobility. A driving force of the global economy resides in the capacity of transport systems to ship large quantities of freight and to accommodate vast numbers of passengers. The world has become interconnected at several scales. This new geographical dimension transcends a more traditional perspective of transportation that focused on the city or the nation.

At the beginning of the twenty-first century, the geography of transportation is fundamentally being redefined by global, regional and local demands. Bus Rapid Transit (BRT) is therefore, an innovative bus system with sophisticated vehicles, high speed and frequency, distinctive image and comfort, 
inflexible busway that target improved integration with cities and lucrative promise of flexible capacity and high quality at lower costs than the railway systems. In contrast to the conventional bus systems which operate predominantly in mixed traffic, on streets or dedicated lanes, Cervero (2013) noted that BRT achieves high capacity by canalizing passenger flows in a system of segregated busway, partially or fully separated from other traffic. Even though it originates from the late 1930s, BRT achieved world fame after the successes in Curitiba and Bogota. There is an on-going global public transportation renaissance in the last two decades with approximately 100 completed BRT systems and a near equal number under development across the globe (Wright, 2011).

Lagos State, Nigeria, being one of the fastest growing cities in the world, is faced with numerous challenges of which efficient and adequate transportation is one of them. Census 2006 showed that Lagos has an estimated population of 17 million but most of the total population is clustered around a relatively small geographical space (Braimoh and Onishi, 2007), thereby causing a great strain on the existing public infrastructure (Odufuwa, 2010). Mobereola (2009) stated that in order to address some of the problems of public transportation in Lagos, the state government on 17th March, 2008, introduced Bus Rapid Transit (BRT) which provides Lagos and its environs, a more convenient and reliable means of commuting around the city.

\section{LITERATURE REVIEW}

Transportation is no doubt an indispensable catalyst for activating and stimulating the tempo of economic, social, political, and strategic development in any society. Thus, effective and efficient functioning of urban centres depends on the provision of basic infrastructures one of the most important being transport. This implies that transport infrastructure has to be rationally developed to ensure that movement of people and goods takes place speedily, economically, safely, comfortably and in an environmentally-friendly manner (Sumaila, 2012).

As compliments, there must be strategic transport infrastructural development to enable all available transport modes to be properly harnessed, stream-lined and integrated for socio-economic and defense purposes (Gbujie, 2003). But whether transport infrastructure is rationally or strategically developed, the benefits could only be optimized if it promotes a sustainable transport system that guarantees safe, reliable, efficient and environmentally-friendly movement of people and goods, if they must overcome the congestion monster that bedevils urban centres globally, that is, congestion of people, houses and traffic (Ogunsanya, 1995). These problems constituted the nation's experience in Lagos to the extent that their magnitude affected the national psyche.

A convenient starting point according to Olayemi (1981) is a consideration of transportation as a material or inventive infrastructure. This qualification is necessary to differentiate transportation from a set of physical structures which may be termed as consumptive infrastructural stock. According to him, transportation shares with other inventive infrastructures the following attributes: first, this infrastructural type is very expensive, has a long economic life, and possesses a high capital-output ratio and shows, in the short run, only small capacity and growth effects. Secondly, this category of infrastructure has significant external effects on directly productive investments in other sectors of the economy. Further, inventive infrastructural type is collectively utilized thereby making a cost-based individual price for its use very difficult to establish. Thus, financing this type of infrastructure is consequently done on collective basis.

However, the role of transport in promoting a nation's overall development can hardly be overemphasized. According to Adefolalu 1981 and Ogundare (1992), transport is a key factor in development and in certain aspects of development it is the key factor. The provision of transport facilities and services is very crucial to the economic, political, social and cultural life of a nation. There is hardly any aspect of a nation's development in which transport is not an essential ingredient since there is always the need to collect, assemble, move or transfer, and distribute people and commodities. 
Therefore, transportation plays an important role in the political, economic and social development of any society. It constitutes the main avenue through which different parts of the society are linked together. Hailey (1957) opined that there seems to be no other type of development which can speedily change economic and social conditions of backward nations except transport. Olomola (2003) is of the opinion that inadequate provision of transportation infrastructure is the basis of the high incidence of poverty across various Nigerian communities. Transportation infrastructure facilitates the mobility of the means of production thus improving productivity and reducing cost, thereby enhancing competition. It moves goods and people to facilitate production and trade and consequently spurring growth. A good transport system is the connecting basis of all socio-economic interactions and economic activities linking and integrating the country to the world. The demand for effective transportation increases when economic activities and organization expand.

Transportation includes sea, rail, air, and road transportation. Road transportation is the most common type of transportation in Nigeria. It is responsible for moving substantial proportion of goods from the rural areas to the urban centres, and for moving goods from the interior to the ports for exportation. The challenges of road transportation are many. These include dilapidating condition of roads, lack of maintenance culture, abandoned road projects, and inadequate passenger capacity among others (Oni and Okanlawon, 2008; Ogundare, 2013). The need for adequate and efficient road transportation in urban centres, especially Lagos cannot be overemphasized given its position as the commercial nerve centre of the nation and with the perpetual rural-urban drift in the nation.

The demand for transport is undoubtedly a derived demand since it arises from the desire to use it for achieving certain goals. Transportation, then, according to Adefolalu (1981), Ogunbodede (1999) and Ogundare (2013) is primarily a service industry, or a service sector of the economy. Really, the role of transport is not limited to merely servicing other things, for it is often used as a tool of development especially in under-developed parts of a country or in newly colonized areas, where such transport routes are described as development lines, built in anticipation of the development of traffic. However, through the operation of its services, transport contributes to the economy and general development in its own right by creating jobs and employment, enabling the acquisition of certain skills, permitting acquisition of entrepreneurship, providing outlets for investment and channels of capital formation and providing access for resource reconnaissance and land surveys. Through the process of constructing route-ways for different modes, especially land routes, man has gained tremendous knowledge of overcoming terrain and adverse environmental conditions, for example in areas of complex geological structure, in arid deserts, and in Arctic and sub-arctic environments.

\section{RESEARCH HYPOTHESIS}

$\mathbf{H}_{0}$ : The perceived socio-economic benefits of BRT in addressing transportation challenges to create a functional, liveable and sustainable city are not significantly higher than the major challenges of BRT to commuters in Lagos State.

\section{STUDY AREA}

Lagos State, the study area was created in 1967 when Nigeria was restructured into a Federation of twelve states. Lagos as a trading port has a recorded history dating back to the Portuguese explorers of the 16th century. Located in the south western part of Nigeria, Lagos State occupies 3,345 square kilometers. It shares boundaries with Ogun State both in the North and East and is bounded on the west by the Republic of Benin. In the South it stretches for 180 kilometers along the coast of the Atlantic Ocean (Fig.1). It is the smallest State in the Federation, and occupies an area of which 22\% or $787 \mathrm{sq} . \mathrm{km}$ consists of lagoons and creeks. The land on the northern fringe of the state has soils which do not rise very much above sea level (Uka, 2017; LASG, 2017). 


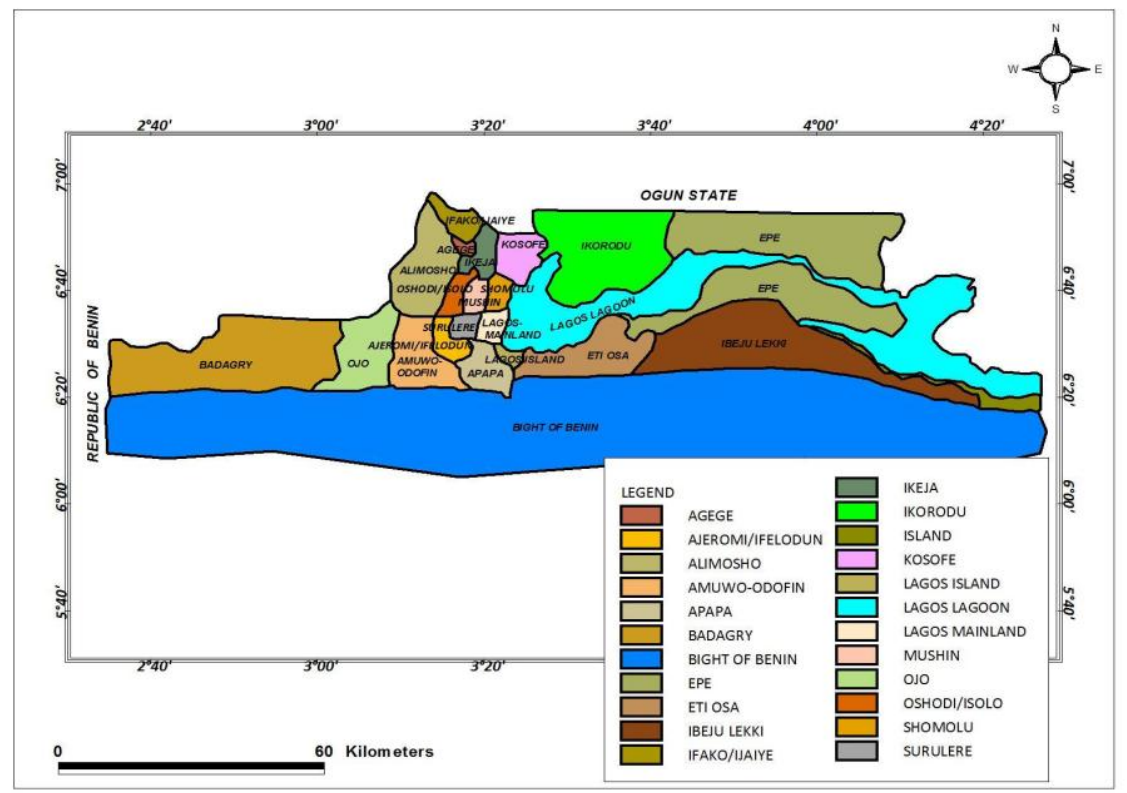

Fig1. Map of Lagos State Showing all the Local Government Area

Source: Ministry of Physical Planning, Lagos State

Consequently, Lagos State because of its chaotic and traffic jam couple with its exponential increase in the population size which has led to the launching of the Lagos Bus Rapid Transit (BRT) - Lite in March 2008, the new Bus Rapid Transit (BRT) system provides Lagos commuters with a clean, affordable, and reliable means of transport. In addition, the BRT ensures fast, comfortable and costeffective service. The pilot BRT corridor was chosen through the feasibility study and today BRT lite operates along Ikorodu road, Western Avenue, and Eko Bridge, a key radical highway that marks the 22 kilometres connection between Mile 12 and Lagos Island (Fig. 2) of which 65 percent is physically segregated from the regular roadway and 20 percent separated by road markings. Prior to implementation, the highway enjoyed a wide dual carriage way varying between two and three lanes in each direction and the system was projected to carry about 10,000 passengers per direction per hour during peak travel hours. The Lagos BRT runs 16-hour operation running from $6.00 \mathrm{am}$ to $10.00 \mathrm{pm}$ while the bus has a maximum seating capacity of 46 . It should be noted that, the BRT system is the first of its kind in Sub Saharan Africa. The Lagos BRT-lite draws from the experience of Bogota (Columbia) and Curitiba (Brazil) but uses the concept in African context as BRT-lite (i.e. high quality) bus system that is affordable in the local context but retaining as many of the most desirable BRT characteristics as possible.

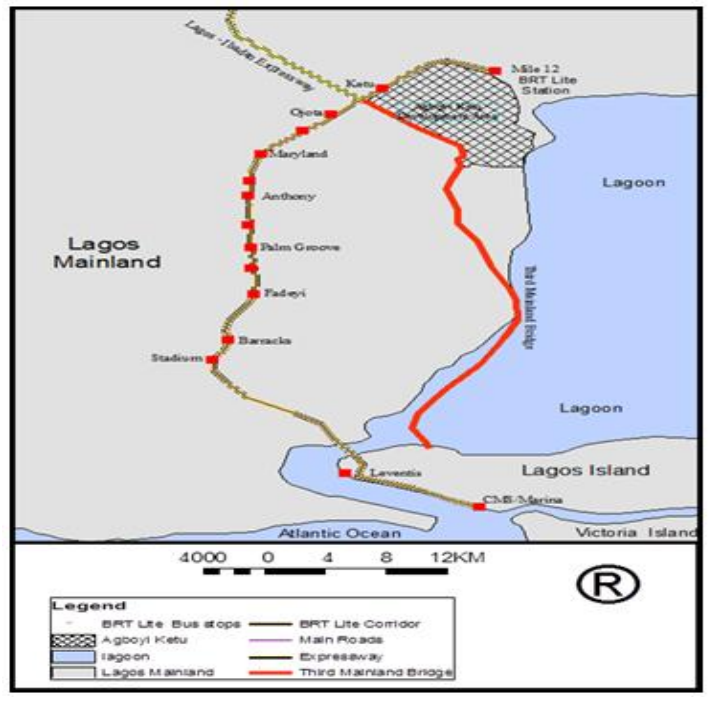

Fig2. Lagos state Showing BRT Route

Source. Lagos State Ministry of Physical Planning (2015) 


\section{Methodology}

The methodology adopted in this study is geared towards the ultimate realization of the aim of the study. A pilot study was conducted in the area to explore information about BRT infrastructures and services, characteristics of commuters, nature of transportation, traffic situation and safety, means of getting to BRT bus stops and the basic BRT corridors. The study was purposively based on the data drawn from a target population which is Lagos BRT users. The sampling unit was therefore based on pilot study and published tables of Israel (2013) and Olowosegun, Olorunfemi, Akinsehinwa and Okoko (2014), using the number of BRT fleets in operation and their capacities. With the use of 245 buses in the fleet at peak periods and an average capacity of 44 passengers, a total number of 10,780 passengers form the sample frame. Taking a Precision Level of 5 percent of the total number where confidence level is 95 percent, this gives a sample size of 539 respondents. With the assistant of ticket operators at the terminal bus stops 539 questionnaire were distributed to commuters on first come first served basis. The three peak hours, that is the morning, afternoon and evening peaks were taking into consideration where 200 questionnaire were distributed each at morning and evening peaks and 139 questionnaire distributed at afternoon peak hour making a total of 539 questionnaire in all. The data collected were analyzed using both descriptive and inferential statistics. The results were shown using tables, graphs and charts. The Scheffe post-hoc statistical method was used to examine if BRT has significant difference in reducing transportation challenges in Lagos State.

\section{Data Presentation And Analysis}

The data generated from the study were presented and analyzed according to the socio-economic characteristics and hypothesis that guided the study.

\subsection{Sex of the Respondents}

The data collected on the sex of the respondents shows that $55.3 \%$ were males and $44.7 \%$ females. The study revealed that there are more males that patronize and use BRT in Lagos State than females as shown in Table 1.

Table1. Sex Distribution of BRT Commuters

\begin{tabular}{|l|l|c|c|}
\hline S/N & Gender & Frequency of Commuters & \% of Total \\
\hline 1. & Male & 298 & 55.3 \\
\hline 2. & Female & 241 & 44.7 \\
\hline & Total & $\mathbf{5 3 9}$ & $\mathbf{1 0 0 . 0}$ \\
\hline
\end{tabular}

Source: Author's Field Survey, 2018

\subsection{Age of the Respondents}

The data collected on the age of the respondents was summarized and the responses are as shown in Table 2. From the table, it was revealed that $17.4 \%$ of the respondents are less than 20 years. The categories of people in this age are school children who use the BRT to school and apprentices engaging in one work or the other. Also $12.4 \%$ of the respondents who uses BRT are over 60 years, which shows that the aged also uses BRT either for visiting, marketing, religious, or recreational purposes. Of all the commuters, $70.2 \%$ are between ages 21 and 60 years. Majority of the commuters, that is, $37.7 \%$ are between the age of 21 and 40 years while $32.5 \%$ are within the age of $41-60$ years.

Table2. Age Distribution of BRT Commuters

\begin{tabular}{|l|l|c|c|}
\hline S/N & Age Group & Frequency of Commuters & \% of Total \\
\hline 1. & $<20$ Years & 94 & 17.4 \\
\hline 2. & $21-40$ Years & 203 & 37.7 \\
\hline 3. & $41-60$ Years & 175 & 32.5 \\
\hline 4. & $>60$ Years & 67 & 12.4 \\
\hline & Total & $\mathbf{5 3 9}$ & $\mathbf{1 0 0 . 0}$ \\
\hline
\end{tabular}

Source: Author's Field Survey, 2018

Consequently, the $70.2 \%$ of BRT commuters that falls within age 21 and 60 years implies that they are within economically active working age groups where production level is expected to be high and these middle aged groups constitute the most benefited of the BRT transport services and have more 
access than those aged and young commuters who are vulnerable and are often in need of transport assistance. Figure 3 further shows the distribution of the combined age of the respondents.

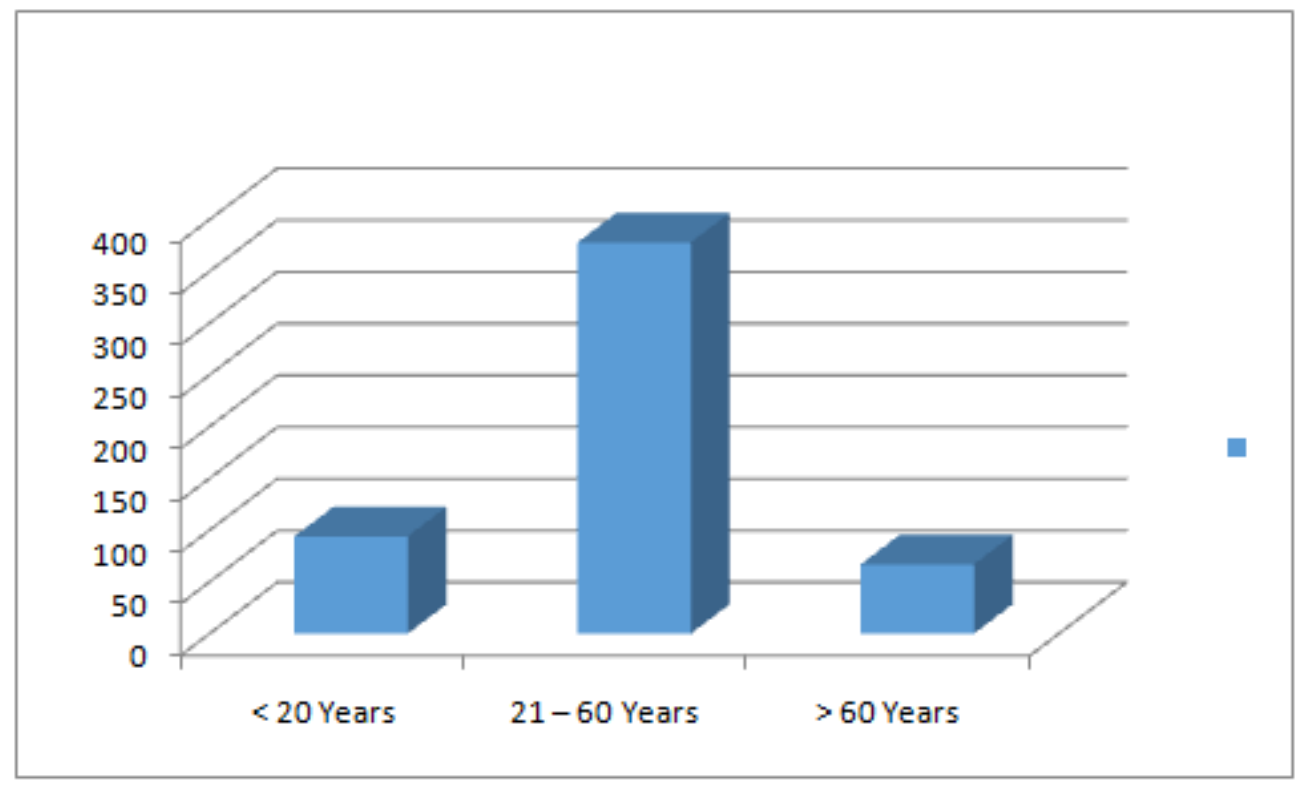

Figure3. Bar Chart Showing Age Grade of BRT Commuters

\subsection{Educational Qualification of the Respondents}

The levels of education of the respondents were sought for and it was revealed that most of them are educated. 50.5\% of respondents are holders of HND/B.Sc. and above, while $31.9 \%$ claimed to have between OND/NCE. However, 15.6\% of the commuters had between SSCE and below while only $2 \%$ claimed not to have formal education. The reason for having more graduates could be adduced to the fact that the BRT corridors link the economic nerve centre of the study area; that is, Lagos Island where there are more offices and administrative jobs that require skilled workers. The fact that questionnaires were administered at the peak periods when people go and come back from work also encourage the large turn-out of graduates in the study area. Figure 4 revealed the educational status of the respondents.

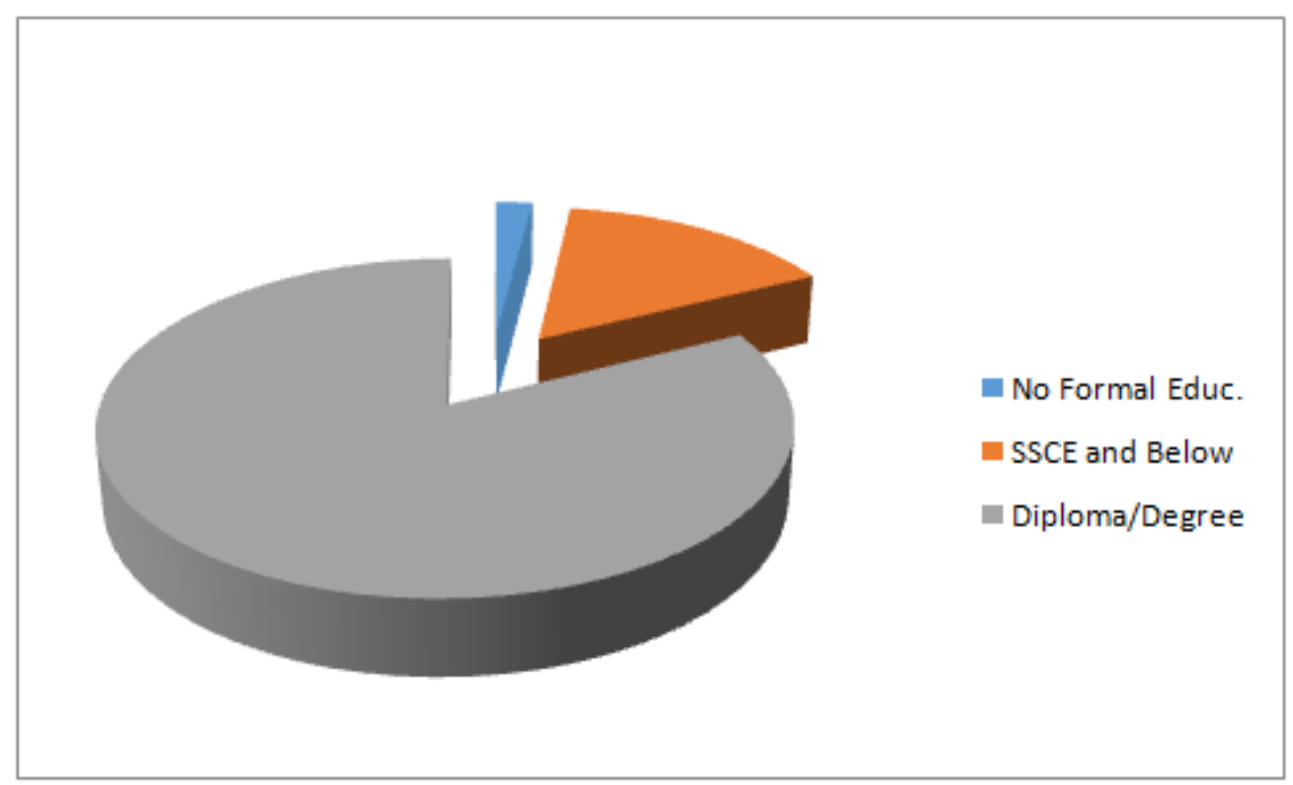

Figure4. Burble Pie Showing BRT Commuters' Academic Qualifications

\subsection{Employment Status of BRT Commuters}

The survey of respondents' employment status was revealed in Table 3 and Figure 5. Majority of those who use BRT are employed people. They probably use BRT because of the perceived 
advantages of the scheme. Of the total 539 commuters that were sampled, $26.2 \%$ are civil/public servants while $45.1 \%$ were privately or self-employed. Only $17.8 \%$ claimed to be student/apprentice and $10.9 \%$ unemployed or retired.

Table3. Employment Status of BRT Commuters

\begin{tabular}{|l|l|c|c|}
\hline S/N & Employment Status & Frequency of Commuters & \% of Total \\
\hline 1. & Civil/Public Servants & 141 & 26.2 \\
\hline 2. & Private/Self Employed & 243 & 45.1 \\
\hline 3. & Student/Apprentice & 96 & 17.8 \\
\hline 4. & Unemployed/Retired & 59 & 10.9 \\
\hline & Total & $\mathbf{5 3 9}$ & $\mathbf{1 0 0 . 0}$ \\
\hline
\end{tabular}

Source: Author's Field Survey, 2018

Furthermore, the employment status revealed two statuses of commuters of BRT, that is employed and unemployed commuters. From Figure 5, 71.3\% are employed while 28.7\% are unemployed. This fact supports $82.4 \%$ of the commuters that claimed to be diploma or degree holders in Figure 4 . The assertion also supports the pattern of movement during peak hours. Out of the 539 respondents sampled, 263 of them representing $48.8 \%$ claim to have a car of their own. This indicates that some people who have cars also patronize the BRT for some reasons which stems from reliability, free of congestion, speed, comfortability and ease of use. Of those who use the BRT, majority of them $(84.2 \%)$ agree that BRT is faster than using their own cars or other public commercial buses. This is probably due to the fact that BRT have dedicated lanes along the corridors.

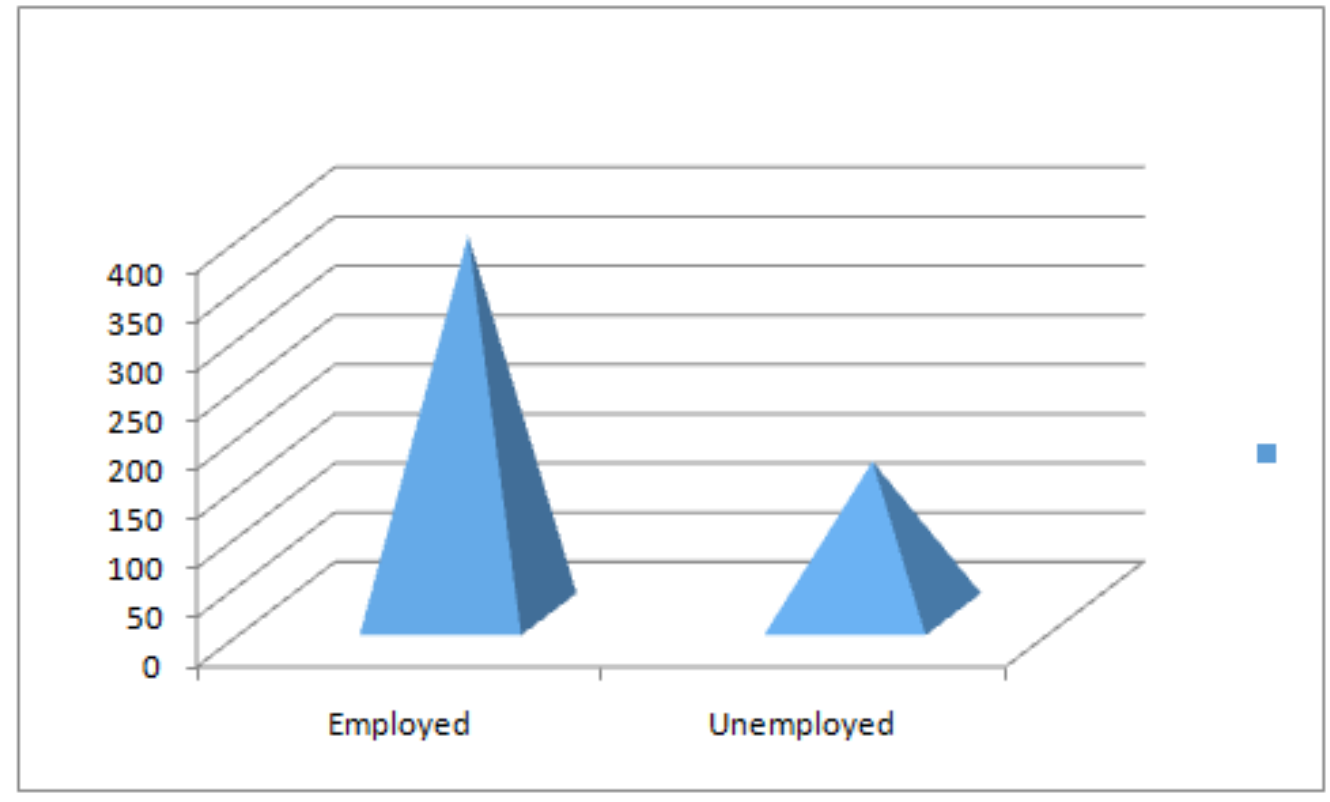

Figure5. Pyramid bar Chart Showing Employment Status of BRT Commuters.

\subsection{Income Level of Commuters}

The survey conducted on average monthly income of commuters' shows that $10.4 \%$ received monthly income of less than $\$ 18,000$, while $18.9 \%$ claimed to earn between $\$ 18,000$ and $\$ 50,000$ monthly. Also, $20 \%$ of the commuters earn between $\$ 50,001$ and $\$ 100,000$, while $19.1 \%$ claimed to earn more than 100,000 monthly. $6.3 \%$ of the respondents that claimed no income are probably students or apprentices who don't have any source of income as well as retired or unemployed commuters. The total number of commuters without income and those with income of less than 18,000 monthly is almost equal to the number of unemployed/retired, and students/apprentices in Table 3.

Consequently, the classification of BRT commuters into income categories was based on the estimate of the Nigeria Bureau of Statistics (2012), where workers with monthly income below $\$ 18,000$ are categorized as low income earners. As depicted in Figure 6, the study revealed that $29.3 \%$ of the respondents earn below $\$ 50,000$ monthly; an indication that living condition is low and poverty rate in the country is high. It also points to reasons for agitation in salary increase and minimum wage to 
$\$ 50,000$. However, for the purpose of the research, commuters that earn above $\$ 50,000$ to $\$ 150,000$ are classified as middle income earners $(39.1 \%)$ while commuters that earn above 150,000 are classified as high income earners $(25.3 \%)$.

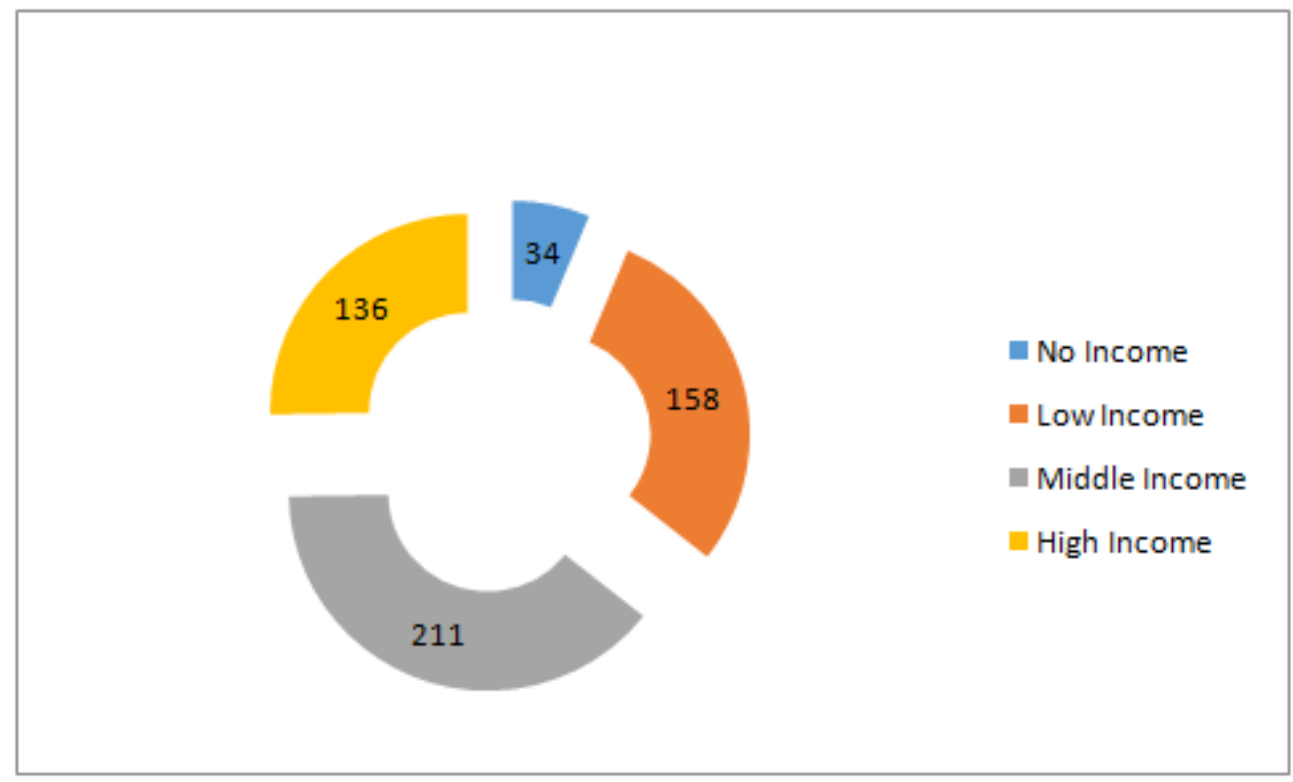

Figure6. Pie Chart Showing Category of Income of Commuters (Monthly)

\subsection{Average Waiting Time to Board BRT Buses}

It was revealed in the study that $53.2 \%$ of BRT commuters which is above average spent between 1 10 minutes before boarding a BRT bus. $41.4 \%$ of the respondents also spent between $11-20$ minutes waiting time at BRT bus stops while only $5.4 \%$ spent over 20 minutes before boarding a BRT bus. This however further proved efficiency and adequacy of the scheme as shown in Figure 7.

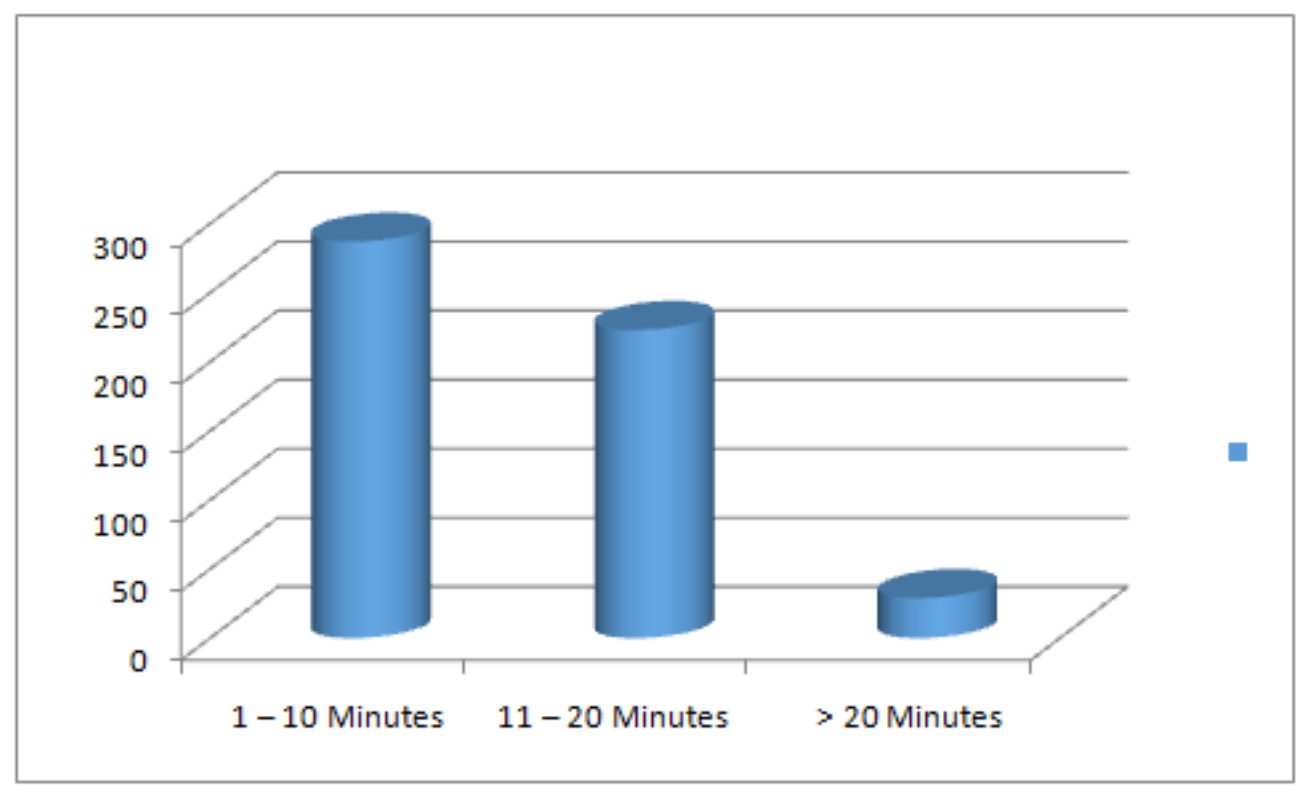

Figure7. Average Waiting Time of Commuters at BRT Bus Stop

\subsection{Travel Frequency of BRT Commuters}

The study revealed that $34.7 \%$ of commuters using BRT journey with it every day, $8.2 \%$ use BRT $1-$ 2 times a week, and $15.2 \%$ use BRT 3 - 4 times a week while $41.9 \%$ journey with BRT $5-6$ times a week. Figure 8 revealed that majority of the respondents (76.6\%) use BRT for one purpose or the other on daily basis especially those using it to go to work and business purposes. Working days are always five or six days in a week, five days for government workers and some private establishments, and some on daily basis especially those on shifting jobs. This has greatly influence the frequency of 
use of BRT. Those who use BRT once or twice in a week (8.2\%) may use it for purpose of visiting, recreation or for leisure, while those that use BRT between $3-4$ times in a week $(15.2 \%)$ may be for the purpose of shopping or religious activities. The implication of this is that more people commute with BRT every day and one of the contributing factors while demand for BRT exceeds supply at the peak hours is the affordable charges, safety, comfort ability and reliability of the scheme.

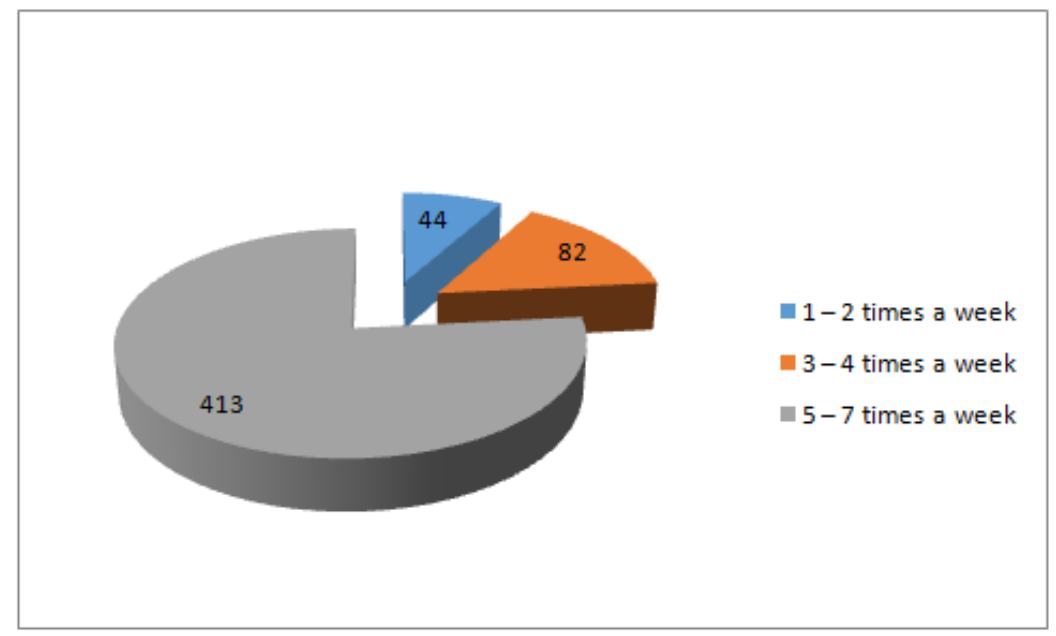

Figure8. Travel Frequency of BRT Commuters

Consequently, the introduction of the BRT service has influenced some commuters to change their travel patterns. $35.7 \%$ of the commuters interviewed said that their use of the service had led to a change in the time of day that they travelled. $78.5 \%$ of the commuters claimed that the speed and $79.4 \%$ claimed that reliability of the BRT services allowed them to travel at the time they wanted rather than having to leave early to ensure reaching their destinations on time. The $76.6 \%$ of the respondents that use BRT between $5-6$ days and on daily basis stated that they made more trips using BRT system for positive reasons such as the reduced journey time, cost, comfort, or improved accessibility. Of the respondents who said they made fewer trips, $1-2$ times a week were attributed to the reduced requirement to transfer to another vehicle, which again is positive, if not strictly constituting a change in the number of trips.

\subsection{Socio-Economic Benefits of BRT in Lagos State}

Access to transport in most cases is complicated as lack of adequate accessibility and affordability of transport particularly public transport depicts inefficiencies in service delivery. Adequate access to transport is an important element for human welfare, economic opportunities and social benefits with a number of multiplier effects for socio-economic development, yet it is often undermined and assumes that all urban dwellers have equal access to public transport relative to their rural counterparts (Orekoya, 2012).

Table 4 indicates the summary of the respondents' responses to the perceived socio-economic benefits of BRT and how it addressed transportation challenges in Lagos metropolis as well as the calculated Mean Weight Value (MWV) and the Gross Mean Weight Value (GMWV) on the respondents' notions. As a rule (Likert Scale) the variable whose MWV fell above the cut-off point (GMWV) 2.75 were accepted while variable whose MWV fell below this cut-off point were rejected.

The perceived socio-economic benefits of BRT and how it addressed transportation challenges in Lagos State include the notion that the prices charged are affordable (2.94); it helped to reduce commuting time and stress (3.25); BRT corridors are always in good condition (2.98); the buses are neat with good quality seats (3.14); it offers more value for money than other means of road transport in Lagos (3.10); increase transit ridership (3.16); catalyst to development and promotes smart growth (3.37); improves urban design (3.10); and reduced emissions of obnoxious gases and pollution (2.81) are the accepted effects of socio-economic benefits of BRT in Lagos State.

Factors such as BRT is always available (2.53); tickets are always readily available and accessible (2.55); regular use of BRT has little significant effect on income (2.14); adequate security at the bus stops (2.46); BRT helped to reduce traffic congestion in Lagos (2.16); the current routes plied by BRT 
are adequate (1.6); the drivers are disciplined, well behaved, drive moderately and obey traffic regulations (2.60); and increased revenues to public sector (2.74) are rejected as they affect socioeconomic benefits of BRT in creating functional, liveable and sustainable city in Lagos State.

Table4. Socio-Economic Benefits of BRT in Lagos Metropolis

\begin{tabular}{|c|c|c|c|c|c|c|c|c|c|c|c|c|c|}
\hline \multirow[t]{2}{*}{$\mathbf{S} / \mathbf{N}$} & \multirow[t]{2}{*}{ Benefits } & \multicolumn{4}{|c|}{ Responses } & & \multicolumn{4}{|c|}{ Likert Conversion } & & \multirow[b]{2}{*}{ 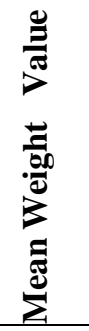 } & \multirow[b]{2}{*}{ 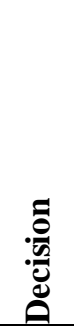 } \\
\hline & & 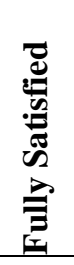 & 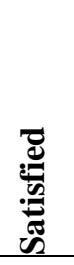 & 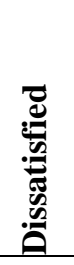 & 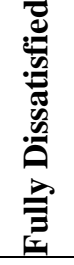 & $\stackrel{\bar{\Xi}}{\theta}$ & 4 & 3 & 2 & 1 & है & & \\
\hline 1 & $\begin{array}{l}\text { Prices charged are } \\
\text { affordable }\end{array}$ & 145 & 264 & 81 & 49 & 539 & 580 & 792 & 162 & 49 & 1583 & 2.94 & Acc \\
\hline 2 & $\begin{array}{l}\text { BRT is always } \\
\text { available }\end{array}$ & 114 & 167 & 146 & 112 & 539 & 456 & 501 & 292 & 112 & 1361 & 2.53 & Rej \\
\hline 3 & $\begin{array}{l}\text { Tickets are always } \\
\text { readily available and } \\
\text { accessible }\end{array}$ & 107 & 189 & 139 & 104 & 539 & 428 & 567 & 278 & 104 & 1377 & 2.55 & Rej \\
\hline 4 & $\begin{array}{l}\text { Help to reduce } \\
\text { commuting time \& } \\
\text { stress }\end{array}$ & 206 & 277 & 43 & 13 & 539 & 824 & 831 & 86 & 13 & 1754 & 3.25 & cc \\
\hline 5 & $\begin{array}{l}\text { The roads are in good } \\
\text { condition }\end{array}$ & 174 & 221 & 103 & 41 & 539 & 696 & 663 & 206 & 41 & 1606 & 2.98 & ce \\
\hline 6 & $\begin{array}{l}\text { Regular use of BRT } \\
\text { has little sig. effect on } \\
\text { income }\end{array}$ & 72 & 90 & 219 & 158 & 539 & 288 & 270 & 438 & 158 & 1154 & 2.14 & Rej \\
\hline 7 & $\begin{array}{l}\text { The buses are neat and } \\
\text { quality of seats is } \\
\text { good }\end{array}$ & 171 & 293 & 57 & 18 & 539 & 684 & 879 & 114 & 18 & 1695 & 3.14 & Acc \\
\hline 8 & $\begin{array}{l}\text { Security is adequate at } \\
\text { the bus stops }\end{array}$ & 73 & 201 & 164 & 101 & 539 & 292 & 603 & 328 & 101 & 1324 & 2.46 & Rej \\
\hline 9 & $\begin{array}{l}\text { BRT helped to reduce } \\
\text { traffic congestion in } \\
\text { Lagos }\end{array}$ & 199 & 161 & 111 & 68 & 539 & 272 & 333 & 398 & 161 & 1164 & 2.16 & Rej \\
\hline 10 & $\begin{array}{l}\text { The current routes } \\
\text { plied by BRT are } \\
\text { adequate }\end{array}$ & 2 & 26 & 244 & 248 & 539 & 84 & 78 & 488 & 248 & 898 & 1.67 & Rej \\
\hline 11 & 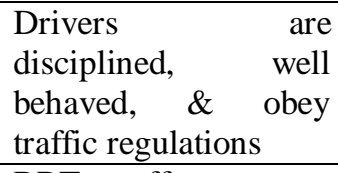 & 104 & 182 & 188 & 65 & 539 & 416 & 546 & 376 & 65 & 1403 & 2.60 & Rej \\
\hline 12 & $\begin{array}{l}\text { BRT offers more } \\
\text { value for money than } \\
\text { others }\end{array}$ & 187 & 265 & 43 & 44 & 539 & 748 & 795 & 86 & 44 & 1673 & 3.10 & Acc \\
\hline 13 & $\begin{array}{l}\text { Increased revenues to } \\
\text { public sector }\end{array}$ & 144 & 163 & 181 & 51 & 539 & 576 & 489 & 362 & 51 & 1478 & 2.74 & Rej \\
\hline 14 & $\begin{array}{ll}\begin{array}{l}\text { Increased } \\
\text { ridership }\end{array} & \text { transit } \\
\end{array}$ & 209 & 246 & 40 & 38 & 539 & 836 & 738 & 92 & 38 & 1704 & 3.16 & Acc \\
\hline 15 & $\begin{array}{l}\text { A catalyst to devt and } \\
\text { promote smart growth }\end{array}$ & 274 & 207 & 41 & 17 & 539 & 1096 & 621 & 82 & 17 & 1816 & 3.37 & Acc \\
\hline 16 & 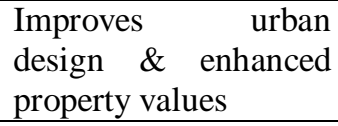 & 216 & 195 & 91 & 37 & 539 & 864 & 585 & 182 & 37 & 1668 & 3.10 & Acc \\
\hline 17 & $\begin{array}{l}\text { Reduced obnoxious } \\
\text { gases \& pollution of } \\
\text { the envmt }\end{array}$ & 168 & 184 & 106 & 81 & 539 & 672 & 552 & 212 & 81 & 1517 & 2.81 & Acc \\
\hline & GMWV & & & & & & & & & & & 2.75 & \\
\hline
\end{tabular}

Source: Author's Field Survey, 2018

International Journal of Research in Geography (IJRG) 
Socio-Economic Importance of Bus Rapid Transit: A Panacea to Sustainable Transport Development in Nigeria

\section{Test of Hypothesis}

$\mathbf{H}_{0}$ : The perceived socio-economic benefits of BRT in addressing transportation challenges to create a functional, liveable and sustainable city are not significantly higher than the major challenges of BRT to commuters in Lagos metropolis.

Table5. F-test Statistics Summary of Socio-economic Benefits and Challenges of BRT

\begin{tabular}{|l|l|l|l|l|l|l|}
\hline Source & Type III Sum of Squares & Df & Mean Square & F-cal & F-tab & Sig. \\
\hline Corrected Model & $357.887^{\text {a }}$ & 3 & 119.296 & 1029.943 & 2.600 & .000 \\
\hline Intercept & 4630.742 & 1 & 4630.742 & 39979.588 & & .000 \\
\hline CHALLENGES & 357.887 & 3 & 119.296 & 1029.943 & & .000 \\
\hline Error & 61.968 & 535 & 116 & & & \\
\hline Total & 5069.000 & 539 & & & & \\
\hline Corrected Total & 419.855 & 538 & & & & \\
\hline
\end{tabular}

R Squared $=.852$ (Adjusted R Squared $=.852$ )

\section{Source: Computer output}

The result presented in Table 5 revealed interactive effect of benefits derived from BRT on the challenges of BRT to the commuters. It was found that the F-cal $=1029.943, \mathrm{df}=(3 ; 535)$ was found greater than Table value (2.600) at 0.05 level of significant. This led to the rejection of the hypothesis. Thus, the perceived socio-economic benefits of BRT are significantly higher than challenges of BRT to commuters in Lagos metropolis. To further affirmed that the perceived socio-economic benefits of BRT are significantly higher than challenges of BRT to commuters in Lagos metropolis, Scheffe posthoc test was carried out as shown in Table 6.

Table6. Scheffe Post-hoc test on Socio-Economic Benefits and Challenges of BRT

\begin{tabular}{|c|c|c|c|c|c|c|}
\hline (I) Challenges & (J) Challenges & Mean Difference (I-J) & Std. Error & Sig. & \multicolumn{2}{|c|}{\begin{tabular}{|l}
$95 \%$ Confidence Interval \\
Lower Bound Upper Bound
\end{tabular}} \\
\hline \multirow{3}{*}{ SD } & $\mathrm{D}$ & $-1.37062^{*}$ & .04014 & .000 & -1.4832 & -1.2581 \\
\hline & $\mathrm{A}$ & $-1.67448^{*}$ & .04134 & .000 & -1.7904 & -1.5585 \\
\hline & SA & $-2.38281^{*}$ & .04505 & .000 & -2.5091 & -2.2565 \\
\hline \multirow{3}{*}{ D } & SD & $1.37062^{*}$ & .04014 & .000 & 1.2581 & 1.4832 \\
\hline & $\mathrm{A}$ & $-.30386^{*}$ & .03887 & .000 & -.4129 & -.1949 \\
\hline & SA & $-1.01220^{*}$ & .04279 & .000 & -1.1322 & -.8922 \\
\hline \multirow{3}{*}{ A } & SD & $1.67448^{*}$ & .04134 & .000 & 1.5585 & 1.7904 \\
\hline & $\mathrm{D}$ & $.30386^{*}$ & .03887 & 000 & .1949 & .4129 \\
\hline & SA & $-.70833^{*}$ & .04392 & 000 & -.8315 & -.5852 \\
\hline \multirow{3}{*}{ SA } & SD & $2.38281^{*}$ & .04505 & .000 & 2.2565 & 2.5091 \\
\hline & $\mathrm{D}$ & $1.01220^{*}$ & .04279 & .000 & .8922 & 1.1322 \\
\hline & $\mathrm{A}$ & $.70833^{*}$ & .04392 & .000 & .5852 & .8315 \\
\hline
\end{tabular}

* The mean difference is significant at 0.05 level of significance

\section{Source: Computer output}

Table 6 revealed that the mean difference of respondents on the benefits derived to challenges encountered in the use of BRT is significantly different at 0.05 . This was ascertained as there were positive values among the variables agreed by the respondents. This shows that commuters count the challenges encountered as negligible and thus prefer to make use of BRT transportation system.

The benefits of using BRT cannot be underestimated. Duarte and Rojas (2012) observed that among 38 Latin American BRT cities with reliable data, average weekday ridership was more 10 times greater than averages for BRT cities of the U.S. and Europe. With 1.65 million passengers per weekday, Bogota's Trans Milenio is the world's most heavily patronized BRT system.

The rationale for BRT investments have broadened with time. Cervero (1998) observed that early BRT adopters, such as Ottawa and Curitiba, built bus ways mainly because they were more affordable than Light Rail Transit (LRT). In recent times, cities like Seoul, Mexico City and Bangkok have invested in BRT as a robust complement to pre-existing urban rail systems. To some developing cities that have historically lacked a viable public transit system, instead of relying on a constellation of 
mostly uncoordinated private bus and informal para-transit services, BRT is part of a major transformation, serving as the backbone of a new public system. This characterizes cities like Lagos, Jakarta, and Ahmedabad.

\section{CONCLUSION}

The importance of public transport in any society has chain of effects; this multiplier effect could be economical, social and environmental. That is why there is need to ensure adequate safety and security in the operation of Lagos BRT as major component of public transport in Lagos State, Nigeria. In history, urbanization is known to be one of the most significant factors of transformation of human society. With rapid urbanization and economic growth comes motorization accompanied by the negative externalities of traffic congestion, which has engendered several challenges and problems to humanity. It is recognized that a sustainable urban transport development cannot be isolated from the broader social and economic development of any country as they are interdependent and are mutually reinforcing components of sustainable development.

\section{RECOMMENDATIONS}

The study therefore recommends that the government of Lagos State should acquire more air condition buses to make the buses readily available especially in peak periods, embark on expansion of more routes to cover other areas yet to be captured in the scheme, such areas as Epe and Badagary axis. Timely repair of the BRT lanes together with other roads in order to ensure free flow of traffic, efficiency, cost effectiveness in the maintenance of buses, durability of the buses, speed and convenience. The scheme requires prudent management of its finances and other resources to ensure and guarantee sustainable service delivery.

The introduction of the BRT scheme in other cities in Nigeria, which will go a long way in reducing global warming that is causing climate change through the reduction in the number of automobiles in our cities that emits carbon in the atmosphere. Construction of bus stops and interchanges that are environmental friendly for the comfort of commuters at all times.

\section{REFERENCES}

[1] Adefolalu, A.A. (1981). Towards a Realisation of Better Transport Services in Nigeria. In Onakomaiya, S.O. and N.F. Ekanem (eds.) Transportation in Nigerian National Development, pp.158-178, Ibadan: Nigeria Institute of Social and Economic Research.

[2] Braimoh, A.K. and Onishi, T. (2007). Spatial Determinants of Urban Land Use Change in Lagos, Nigeria. Land Use Policy, 24: 502-515.

[3] Cervero, R. (1998). The Transit Metropolis: A Global Inquiry. Washington, D.C.: Island Press, pp. 265-296.

[4] Cervero, R. (2013). Bus Rapid Transit (BRT): An Efficient and Competitive Mode of Public Transport. Institute of Urban and Regional Development, University of California, pp. $\quad 1-47$.

[5] Duarte, F. and Rojas, F. (2012). Intermodal Connectivity to BRT: A Comparative Analysis of Bogota and Curitiba. Journal of Public Transportation, 15(2): 1-18.

[6] Gbujie, P.O. (2003). Evaluation of Implementation of Abuja Master Plan: A Case Study of Road Transport Infrastructure, Unpublished M.Sc Thesis, School of Professional Studies, Nigerian Institute of Transport Technology (NITT), Zaria.

[7] Hailey, W.M. (1957). An African Survey, London: OUP.

[8] Israel, G.D. (2013). Determining Sample Size. Agricultural Education and Communication Department, University of Florida. http://edis.ifas.ufl.edu/pdffiles/PD/PD00600.pdf. Asessed May, 2013.

[9] Mobereola, D. (2009). Lagos Bus Rapid Transit: Africa's First BRT Scheme. Urban Transport Series, 1(9): 1-38.

[10] Odufuwa, B.O. (2010). Gender and Safety in Public Transportation: An Explosive Study in Lagos Metropolis, Nigeria. Unpublished Master's Thesis, Institute for Housing and Urban Development Studies, Nigeria.

[11] Ogunbodede, E.F. (1999). Changing Pattern of Land use and Intra-urban Transport Development in Akure, Nigeria. Unpublished Ph.D. Thesis, Submitted to Department of Geography, University of Ilorin, Ilorin, Nigeria.

[12] Ogunbodede, E.F. (2017). Trading Space for a Cost: A Transport Geographer's View, 10th Inaugural Lecture, Adekunle Ajasin University, Akungba Akoko, Nigeria, pp 6-10. 
[13] Ogundare, B.A. (1992). The Major Tourist Products and Potentials in Ekitiland: Prospects and Problems. Unpublished B.Sc Project, Submitted to Department of Geography, Ondo State University, Ado-Ekiti, Nigeria.

[14] Ogundare, B.A. (2013). A Geographical Analysis of Parking Facilities in Akure, Ondo State. Unpublished M.Sc Thesis, Submitted to Department of Geography and Planning Sciences, Adekunle Ajasin University, Akungba Akoko, Nigeria.

[15] Ogunsanya, A.A. (1995). The Future of Transportation in Nigeria, 15th Anniversary Lecture of ANAMMCO, Enugu.

[16] Olayemi, O.A. (1981). Land Transportation: Its Problems and Effects on Nigeria's Economic Development. In Onakomaiya, S.O. \& N.F. Ekanem (eds.) Transportation in Nigerian National Development, pp. 99-121, Ibadan: Nigeria Institute of Social and Economic Research.

[17] Olomola, O. (2003). Regional Transportation Planning in Nigeria: Some Implications of Regional Development, Ile-Ife: University of Ife Press Limited. pp. 137-146.

[18] Olowosegun, A., Olorunfemi, S., Akinsehinwa, F. and Okoko, E. (2014). An Assessment of Public Transport Security and Safety: An Examination of Lagos Bus Rapid Transit (BRT), Nigeria. Civil and Environmental Research, 6(4): 105-116.

[19] Oni, S.I. and Okanlawon, K.R. (2008). Nigeria's Transport Infrastructure Development: An Integral Part of the National Economic Empowerment and Development Strategy (NEEDS), Ethiopian Journal of Environmental Studies and Management, 1(1): 7-18.

[20] Orekoya, T. (2010). The Bus Rapid Transit System of Lagos, Nigeria. A Presentation to United Nations Forum on Climate Change Mitigation, Fuel Efficiency and Sustainable Urban Transport, Seoul, Korea.

[21] Rodrigue, J., Comtois, C. and Slack, B. (2006). The geography of transport Systems. New York: Routledge Publishers, pp 1-5.

[22] Sumaila, A.G. (2012). Sustainable Transportation Management for Federal Capital Territory, (FCT), Paper Presented at a One-day Retreat for Staff of FCT Transportation Secretariat, Abuja, 4th August, 2012.

[23] Wright, L. (2011). Bus Rapid Transit: A Review of recent Advances. In Dimitriou, H., R. Gakenheimer (eds.). Urban Transport in the Developing World: A Handbook of Policy and Practice,(pp. 421-455) Cheltenham, U.K.: Edgar Elgard.

Citation: Babatope Andrew OGUNDARE. "Socio-Economic Importance of Bus Rapid Transit: A Panacea to Sustainable Transport Development in Nigeria” International Journal of Research in Geography. vol 6, no. 1, 2020, pp. 29-41 doi: http://dx.doi.org/10.20431/2454-8685.0601004.

Copyright: (C) 2020 Authors. This is an open-access article distributed under the terms of the Creative Commons Attribution License, which permits unrestricted use, distribution, and reproduction in any medium, provided the original author and source are credited. 